\title{
Pengaruh Efisiensi Modal Kerja dan Likuiditas Terhadap Profitabilitas (Studi kasus pada PT. Mayora Tbk. Cabang Banyuasin)
}

\author{
Anton Kurniawan \\ Universitas Sumatera Selatan \\ Email:_akurniawanaz@gmail.com \\ Agustinus Supriyanto \\ Universitas Sumatera Selatan \\ Email:agnsupriyanto@yahoo.co.id
}

\begin{abstract}
This study aims to analyze the effect of efficiency of Working Capital and Liquidity on Profitability of PT Mayora, Tbk. Data used in the form of primary data and secondary data, primary data, namely financial statements and other financial data obtained directly from PT Mayora, Tbk. In addition, student data is obtained from the internet, and other reference books. The data analysis method used is qualitative and quantitative descriptive analysis. Quantitative analysis using multiple linear regression and testing of calcic assumptions. Qualitative descriptive analysis is by reviewing and analyzing the facts in the field and discussed using theory. The results showed that the efficiency of working capital and liquidity had a significant influence with the value of R Square 0.975 or $97.5 \%$ the efficiency of working capital and liquidity had an effect on the profitability of PT Mayora Palembang, while the remaining $2.5 \%$ was the influence of other factors not examined in this study such as sales.
\end{abstract}

Keywords: Mayora, liquidity, efficiency, working capital, profitability

\section{Abstrak}

Penelitian ini bertujuan untuk menganalisis pengaruh efisiensi Modal Kerja dan Likuiditas terhadap Profitabilitas PT Mayora, Tbk. Data yang digunakan berupa data primer dan data sekunder, data primer yaitu laporan keuangan dan data keuangan lainnya yang diperoleh langsung dari PT Mayora, Tbk. Selain itu juga digunakan data sekuder yang dipeorleh dari internet, dan buku buku referensi lainnya. Metode analisis data yang digunakan adalah analisis deskriftif kualitatif dan kuantitatif. Analisis kuantitatif dengan menggunakan Regresi Linier berganda dan Uji asumsi Kalsik. Analisis deskiftif kualitatif yaitu dengan mengkaji dan menganalisis fakta dilapangan dan dibahas dengan menggunakan teori. Hasil penelitian menunjukkan bahwa efisiensi modal kerja dan likuiditas memiliki pengaruh yang cukup signifikan dengan nilaiu R Square 0,975 atau 97,5\% efisiensi modal kerja dan likuiditas berpengaruh terhadap Profitabilitas PT Mayora Palembang, sedangkan sisanya yaitu 2,5\% merupakan pengaruh faktor-faktor lain yang tidak diteliti pada penelitian ini seperti faktor penjualan.

Keywords: Mayora, likuiditas, efisiensi, modal kerja, profitabilitas

\section{Pendahuluan}

Permasalahan pokok yang sangat penting dan sering kali dihadapi sebuah perusahaan adalah masalah modal kerja, sehingga setiap perusahaan harus memberikan perhatian yang cukup serius terhadapnya. Modal kerja dibutuhkan oleh setiap perusahaan untuk membelanjai operasinya sehari-hari, misalnya : untuk memberikan persekot pembelian bahan mentah, membiayai upah gaji pegawai, dan lain-lain, dimana uang atau dana yang dikeluarkan tersebut diharapkan dapat kembali lagi masuk dalam perusahaan dalam waktu singkat melalui hasil penjualan produksinya. Oleh karena itu, perusahaan dituntut untuk selalu meningkatkan efisiensi kerjanya sehingga dicapai tujuan yang diharapkan oleh perusahaan yaitu mencapai laba yang optimal. 
Selain itu permasalahan kebijaksanaan keuangan perusahaan adalah masalah efisiensi modal kerja. Manajemen modal kerja yang baik sangat penting dalam bidang keuangan karena kesalahan dan kekeliruan dalam mengelola modal kerja dapat mengakibatkan kegiatan usaha menjadi terhambat atau terhenti sama sekali. Sehingga, adanya analisis atas modal kerja perusahaan sangat penting untuk dilakukan untuk mengetahui situasi modal kerja pada saat ini, kemudian hal itu dihubungkan dengan situasi keuangan yang akan dihadapi pada masa yang akan datang. Dari informasi ini dapat ditentukan program apa yang harus dibuat atau langkah apa yang harus diambil untuk mengatasinya.

Mengapa modal kerja merupakan hal yang sangat penting dalam perusahaan? Jawabnya adalah karena meliputi pengambilan keputusan mengenai jumlah dan komposisi aktiva lancar dan bagaimana membiayai aktiva ini. Perusahaan yang tidak dapat memperhitungkan tingkat modal kerja yang memuaskan, maka perusahaan kemungkinan mengalami solvency (tak mampu memenuhi kewajiban jatuh tempo) dan bahkan mungkin terpaksa harus dilikuidasi. Aktiva lancar harus cukup besar untuk dapat menutup hutang lancar sedemikian rupa, sehingga menggambarkan adanya tingkat keamanan (margin safeti) yang memuaskan. Sementara itu, jika perusahaan menetapkan modal kerja yang berlebih akan menyebabkan perusahaan overlikuid sehingga menimbulkan dana mengaggur yang akan mengakibatkan inefisiensi perusahaan, dan membuang kesempatan memperoleh laba.

Besar kecilnya modal kerja dapat ditambah atau dikurangi sesuai kebutuhan perusahaan, artinya modal kerja harus fleksibel,. Menetapkan modal kerja yang terdiri dari kas, piutang, persediaan yang harus dimanfaatkan seefisien mungkin. Besarnya modal kerja harus sesuai dengan kebutuhan perusahaan, karena baik kelebihan atau kekurangan modal kerja sama-sama membawa dampak negatif bagi perusahaan. Modal kerja yang berlebihan terutama modal kerja dalam bentuk uang tunai dan surat berharga dapat merugikan perusahaan karena menyebabkan berkumpulnya dana yang besar tanpa penggunaan secara produktif. Dana yang mati, yaitu dana-dana yang tidak digunakan menyebabkan diadakannya investasi dalam proyek-proyek yang tidak diperlukan dan yang tidak produktif. Disamping itu kelebihan modal kerja juga akan menimbulkan inefisiensi atau pemborosan dalam operasi perusahaan. Indikator adanya manajemen modal kerja yang baik adalah adanya efisiensi modal kerja (Tunggal,2015). Modal kerja dapat dilihat dari perputaran modal kerja (working capital turnover), perputaran piutang (receivable turnover), perputaran persediaaan (inventori turnover). Perputaran modal kerja dimulai dari saat kas diinvestasikan dalam komponen modal kerja sampai saat kembali menjadi kas. Makin pendek periode perputaran modal kerja, makin cepat perputarannya sehingga perputaran modal kerja makin tinggi dan perusahaan makin efisien yang pada akhirnya rentabilitas semakin meningkat.

Varn Horne, (1997) mengemukakanbahwa dalam penentuan kebijakan modal kerja yang efisien, perusahaan dihadapkan pada masalah adanya pertukaran (trade off) antara faktor likuiditas dan profitabilitas. Jika perusahaan memutuskan menetapkan modal kerja dalam jumlah yang besar, kemungkinan tingkat likuiditas akan terjaga namun kesempatan untuk memperoleh laba yang besar akan menurun yang pada akhirnya berdampak pada menurunnya pofitabilitas. Sebaliknya jika perusahaan ingin memaksimalkan profitabilitas, kemungkinan dapat mempengaruhi tingkat likuiditas perusahaan. Makin 
tinggi likuiditas, maka makin baiklah posisi perusahaan di mata kreditur. Oleh karena terdapat kemungkinan yang lebih besar bahwa perusahaan akan dapat membayar kewajibannya tepat pada waktunya. Di lain pihak ditinjau dari segi sudut pemegang saham, likuiditas yang tinggi tak selalu menguntungkan karena berpeluang menimbulkan dana-dana yang menganggur yang sebenarnya dapat digunakan untuk berinvestasi dalam proyek-proyek yang menguntungkan perusahaan (Tunggal,2015)

Persoalan lainnya dalam sebuah perusahaan adalah bagaimana menentukan sumber dana. Pemenuhan kebutuhan dana suatu perusahaan dapat dipenuhi dari sumber intern perusahaan, yaitu dengan mengusahakan penarikan modal melalui penjualan saham kepada masyarakat atau laba ditahan yang tidak dibagi dan digunakan kembali sebagai modal. Pemenuhan kebutuhan dana perusahaan dapat juga dipenuhi dari sumber ekstern yaitu dengan meminjam dana kepada pihak kreditur seperti bank, lembaga keuangan bukan bank, atau dapat pula perusahaan menerbitkan obligasi untuk ditawarkan kepada masyaraat

Menurut Brigham dan Houston (2011) memiliki tiga implikasi penting, yaitu: Pertama, memperoleh dana melalui utang membuat pemegang saham dapat mempertahankan pengendalian atas perusahaan dengan investasi yang terbatas. Kedua, kreditur melihat ekuitas atau dana yang disetor pemilik untuk memberikan marjin pengaman, sehingga jika pemegang saham hanya memberikan sebagian kecil dari total pembiayaan, maka risiko perusahaan sebagian besar ada pada kreditur. Ketiga, Jika perusahaan memperoleh pengembalian yang lebih besar atas investasi yang dibiayai dengan dana pinjaman dibanding pembayaran bunga, maka pengembalian atas modal pemilik akan lebih besar.

Sawir (2011) menyebutkan bahwa leverage dapat digunakan untuk meningkatkan hasil pengembalian pemegang saham, tetapi dengan risiko akan meningkatkan kerugian pada masa-masa suram. Jika perusahaan menggunakan lebih banyak hutang dibanding modal sendiri maka tingkat solvabilitas akan menurun karena beban bunga yang harus di tanggung juga meningkat. Hal ini akan berdampak terhadap menurunnya profitabilitas. Pada dasarnya, jika perusahaan meningkatkan jumlah utang sebagai sumber dananya hal tersebut dapat meningkatkan risiko keuangan. Jika perusahaan tidak dapat mengelola dana yang diperoleh dari utang secara produktif, hal tersebut dapat memberikan pengaruh negatif dan berdampak terhadap menurunnya profitabilitas perusahaan. Sebaliknya jika utang tersebut dapat dikelola dengan baik dan digunakan untuk proyek investasi yang produktif, hal tersebut dapat memberikan pengaruh yang positif dan berdampak terhadap peningkatan profitabilitas perusahaan.

Penelitian yang dilakukan Siwi (2005) tentang analisis pengaruh efisiensi modal kerja, likuiditas, dan solvabilitas terhadap profitabilitas pada perusahaan property dan real estate yang go publik dibursa efek Jakarta pada tahun 1998-2002. Rasio-rasio yang digunakan adalah rasio working capital turnover (WCT), current ratio, debt to equity ratio(DTA) dan return on investment (ROI). Sampel yang digunakan sebanyak perusahaan property dan real estate yang sudah listing dari tahun 1998-2002. Dalam penelitiannya Siwi (2005) menggunakan analisis regresi berganda linier yang hasilnya menunjukkan bahwa secara parsial hanya variabel efisiensi modal kerja (working capital turnover) dan solvabilitas (total debt to total capital assets) yang mempunyai pengaruh terhadap profitabilitas 
(return on investment) sedangkan variabel likuiditas (current ratio) tidak mempunyai pengaruh terhadap profitabilitas (return on investment). Sedangkan secara simultan semua variabel berpengaruh terhadap profitabilitas. Dalam penelitian ini yang membedakan dengan penelitian Siwi (2005) terletak pada sampel dari perusahaan yang digunakan. Penelitian ini menggunakan industri barang konsumsi di Bursa Efek Jakarta tahun 2001-2005 dengan sampel sebanyak 34 perusahaan.

Sementara itu penelitian Faurani (2004) tentang analisis pengaruh modal kerja terhadap profitabilitas dan rentabilitas pada Koperasi Dharma Wanita "Mandalika" Mataram Nusa Tenggara Barat. Dalam penelitian ini menggunakan rasio-rasio profitabilitas (profit margin on sales ratio), rentabilitas (profit margin ratio), modal kerja (profit margin ratio). Metode analisis data yang digunakan dalam penelitian ini adalah menggunakan metode statistik deskriptif, metode statistik inferensial dan metode analisa korelasi. Penelitian ini menunjukkan bahwa modal kerja tidak begitu berpengaruh terhadap profitabilitas dan rentabilitas pada Koperasi Mandalika akan tetapi dapat juga dipengaruhi oleh faktorfaktor lain.

Dani (2003) dalam peneltiannya tentang pengaruh likuiditas, leverage dan efisiensi modal kerja terhadap profitabilitas (studi kasus pada PT Modern Toolsindo Bekasi). Rasio keuangan yang digunakan adalah Current Ratio, Debt to Equyity Ratio (DER), Working Capital Turnover (WCT) dan Return On Invesment. Alat analisis yang digunakan adalah analisis regresi linier berganda. Menggunakan 1 sampel perusahaan dengan menganalisis neraca dan laporan laba rugi tahun 1997-2002. Dengan menggunakan analisis regresi linier berganda yang hasilnya menunjukkan bahwa secara simultan faktor likuiditas, leverage dan efisiensi modal kerja terbukti memiliki pengaruh positif dan signifikan terhadap tingkat profitabilitas PT Modern Toolsindo. Sedangkan secara parsial hanya variabel leverage yang tidak berpengaruh positif terhadap variabel profitabilitas. Dalam penelitian ini rasio-rasio yang digunakan yaitu Working Capital Turnover (WCT), Debt to Total Asset (DTA), Current Ratio dan Return On Invesment (ROI). Sedangkan penelitian yang dilakukan oleh Dani (2003) menggunakan rasio yang sama dengan penelitian ini kecuali pada variabel solvabilitas, pada variabel solvabilitas penelitian ini menggunakan rasio Debt to Earning Ratio (DER).

Penelitian Indri Astuti (2003) tentang mengenai pengaruh manajemen modal kerja terhadap profitabilitas perusahaan automotive and allied product yang go public di BEJ. Variabel yang diteliti dalam penelitian ini yaitu likuiditas, tingkat hutang, efisiensi modal kerja, tingkat kecukupan kas, tingkat perubahan hutang lancar dan profitabilitas. Rasio yang digunakan antara lain likuiditas menggunakan rasio current ratio, tingkat hutang menggunakan rasio leverage ratio, efisiensi modal kerja menggunakan rasio worrking capital turnover (WCT), tingkat kecukupan kas menggunakan rasio cash ratio, tingkat perubahan hutang lancar menggunakan rasio perubahan hutang lancar. Adapun populasi dalam penelitian ini adalah semua perusahaan yang bergerak dibidang sektor industri automotive and allied products yang terdaftar di BEJ, yaitu sebanyak 18 perusahaan. Metode analisis data dalam penelitian ini yaitu analisis regresi linier berganda. Hasilnya bahwa variabel independent likuiditas, leverage ( tingkat hutang), efisiensi modal kerja, tingkat kecukupan kas (cash ratio), perubahan hutang lancar diduga mempunyai pengaruh terhadap variabel dependen yaitu Return On Invesment (ROI) industri 
automotive and allied product tahun 2000-2003. Sedangkan secara simultan terbukti mempunyai pengaruh yang signifikan dan secara parsial terbukti bahwa variabel efisiensi modal kerja berpengaruh positif secara signifikan terhadap profitabilitas dan perubahan hutang lancar berpengaruh negatif secara signifikan terhadap profitabilitas (ROI). Dalam penelitian ini yang membedakan dengan penelitian Indri Astuti (2003) terletak pada variable, rasio-rasio dan populasi. Indri Astuti menggunakan variabel yang lebih banyak yaitu likuiditas, tingkat hutang, efisiensi modal kerja, tingkat kecukupan kas, tingkat perubahan hutang lancar dan profitabilitas. Sedangkan dalam penelitian ini hanya menggunakan 4 variabel yaitu efisiensi modal kerja menggunakan rasio working capital turnover, likuiditas menggunakan rasio current ratio, solvabilitas menggunakan rasio debt to equity ratio (DTA) dan profitabilitas menggunakan rasio return on investment (ROI). Adapun populasi dalam penelitian ini adalah semua perusahaan yang bergerak di sektor industri barang konsumsi yang terdaftar di BEJ yaitu sebanyak 35 perusahaan dari tahun 2001-2005. Alat analisis dalam penelitian ini sama dengan penelitian yang dilakukan oleh Indri Astuti (2003). Berdasarkan studi pendahuluan pada industri barang konsumsi dapat diketahui bahwa terdapat beberapa perusahaan yang memiliki jumlah modal kerja (WCT) yang tinggi tetapi memiliki tingkat profitabilitas yang rendah dan beberapa perusahaan memiiliki modal kerja (WCT) yang rendah tetapi memiliki tingkat profitabilitas yang tinggi. Kenyataan tersebut menyimpang dari teori yang ada, dimana secara teori apabila perusahaan industri barang konsumsi yang memiliki tingkat modal kerja (WCT) yang tinggi maka tingkat profitabilitasnya juga tinggi. Industri barang konsumsi menjadi industri yang penting bagi perkembangan perekonomian bangsa. Hal ini tidak terlepas dari banyaknya perusahaan-perusahaan yang bergerak dalam industri barang konsumsi di Indonesia. Tidak bisa dipungkiri bahwasanya dalam proses produksi barang konsumsi dibutuhkan banyak sumber daya termasuk di dalamnya sumber daya manusia. Oleh karena itu, industri barang kosumsi memiliki peranan dalam menyerap tenaga kerja dan meningkatkan pendapatan pada suatu negara.

PT Mayora Tbk. Perusahaan berdomisili di jalan Palembang Betung KM 18 kecamatan Talangkelapa Banyuasin dengan pabrik berlokasi di KM 18 Talang Kelapa merupakan salah satu perusahaan yang memproduksi barang Konsumsi (makanan). Sesuai dengan pasal 3 anggaran dasar perusahaan ruang lingkup kegiatan perusahaan adalah menjalankan usaha dalam bidang industri, perdagangan serta agen atau perwakilan. Perusahaan mulai beroperasi secara komersial pada bulan Mei 1978. jumlah karyawan perusahaan dan anak perusahaan hingga saat ini sebanyak 5300 karyawan. Didukung oleh jarring distribusi yang kuat, produk PT Mayora Indah Tbk tidak hanya ada di Indonesia namun juga dapat kita jumpai di Negara seberang lautan seperti Malaysia, Thailand, philiphines, Vietnam, Singapore, Hong Kong, Saudi Arabia, Australia, Africa, America dan Italy. PT Mayora Indah Tbk di memiliki 9 lini produk (a) Biskuit : Roma, Better, Slai O Lai, dan Danisa; (b) Permen : Kopiko, Kis, Tamarin, dan Plonk; (c) Wafer : Beng Beng, Astor, dan Roma; (d) Coklat : Choki Choki dan Danisa; (e) Health Food : Energen; (f) Kopi : Torabika; (g) Bubur : Super Bubur; (h) Mi instan: Mi Gelas; (i) Minuman: Vitazone.

Penelitian pada PT Mayora Tbk Cabang Banyuasin dilakukan dengan tujuan: (1) untuk mengetahui bagaimana pengaruh efisiensi modal kerja dan likuiditas terhadap profitabilitas pada PT Mayora Tbk, Cabang Banyuasin, baik secara simultan; (2) untuk 


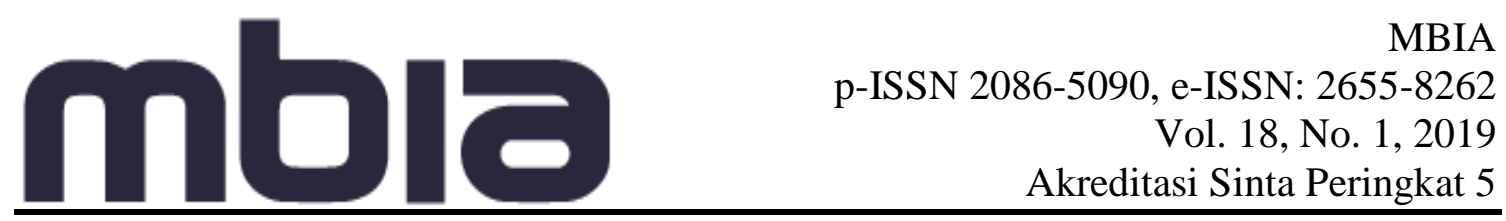

mengetahui bagaimana pengaruh efisiensi modal kerja dan likuiditas terhadap profitabilitas pada PT Mayora Tbk, Cabang Banyuasin, baik secara parsial.

\section{Literature Review}

2.1 Profitabilitas Perusahaan

Profitabilitas adalah kemampuan perusahaan memperoleh laba dalam hubungannya dengan penjualan, total aktiva, maupun modal sendiri (Sartono, 2013). Jumlah laba bersih kerap dibandingkan dengan ukuran kegiatan atau kondisi keuangan lainnya seperti penjualan, aktiva, ekuitas pemegang saham untuk menila kinerja sebagai suatu persentase dari beberapa tingkat aktivitas atau investas Perbandingan ini disebut rasio profitabilitas (profitability ratio). Berikut ini adalah beberapa rasio yang digunakan untuk mengukur profitabilitas adalah sebagai berikut:

Formulasi dari gross profit margin atau GPM adalah sebagai berikut (Sawir,2011):

Penjualan - harga Pokok Penjualan

$\mathrm{GPM}=$

X $100 \%$

Penjualan

Formulasi dari net profit margin adalah sebagai berikut (Sawir,2001):

Laba Setelah Pajak

$\mathrm{NPM}=\frac{\text { Penjualan }}{\mathrm{N}} \mathrm{100 \%}$

Formulasi dari return on investment atau ROI adalah sebagai berikut (Munawir,2011):

Laba Setelah Pajak

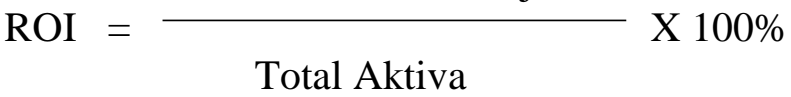

Return on equity atau return on net worth mengukur kemampuan perusahaan memperoleh laba yang tersedia bagi pemegang saham perusahaan atau untuk mengetahui besarnya kembalian yang diberikan oleh perusahaan untuk setiap rupiah modal dari pemilik. Formulasi dari return on equity atau ROE adalah sebagai berikut (Sawir,2011): Laba Setelah Pajak

$\mathrm{ROE}=\frac{\mathrm{Modal} \text { sendiri }}{\mathrm{X}} \mathrm{100 \%}$

\subsection{Modal Kerja}

Pengertian modal kerja terdapat beberapa konsep yaitu (Riyanto, 2015)

Konsep kuantitatif merupakan konsep yang mendasarkan pada kuantitas dari dana yang tertanam dalam unsur- unsur aktiva lancar dimana aktiva ini merupakan aktiva yang sekali berputar kembali dalam bentuk semula atau aktiva dimulai dari yang tertanam di dalamnya akan dapat bebas lagi dalam waktu yang pendek. Dengan demikian modal kerja dalam konsep ini adalah keseluruhan dari jumlah aktiva lancar.

Konsep kualitatif menyatakan bahwa modal kerja adalah sebagian dari aktiva lancar yang benar-benar dapat digunakan untuk membayar operasi perusahaan mampu mengganggu 


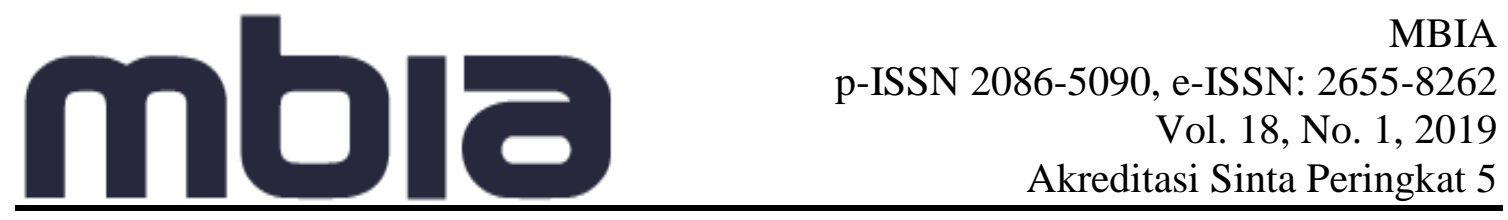

likuiditasnya yaitu yang merupakan kelebihan aktiva lancar diatas utang lancar. Modal kerja dalam pengertian ini sering disebut modal kerja memo (non working capital)

Konsep fungsional menyatakan bahwa modal kerja mendasarkan pada fungsi dari dana dalam menghasilkan pendapatan. Setiap dana yang dikerjakan atau digunakan dalam perusahaan dimaksudkan untuk menghasilkan pendapatan. Pendapatan yang dimaksud adalah pendapatan dalam satu periode accounting (current income) bukan periode berikutnya (future income)

Kebutuhan perusahaan akan modal tergantung pada faktor-faktor sebagai berikut (Tunggal, 2015): (1) sifat atau jenis perusahaan dan (2) waktu yang diperlukan untuk memproduksi dan memperoleh barang yang akan dijual. Sifat atau jenis perusahaan adalah kebutuhan modal kerja tergantung pada jenis dan sifat dari usaha yang dijalankan perusahaan. Waktu yang diperlukan untuk memproduksi dan memperoleh barang yang akan dijual yang menyatakan sumber modal kerja meliputi hal-hal sebagai berikut (Tunggal, 2015): (a) Operasi rutin perusahaan; (b) Laba yang diperoleh dari penjualan surat-surat berharga dan penanaman sementara lainnya; (c) Penjualan aktiva tetap, penanaman jangka panjang/aktiva tak lancar dan lain-lainnya; (d) Pengembalian pajak dan keuntungan luar biaya lainnya; (e) Penerimaan yang diperoleh dari penjulan obligasi dan saham dan penyetoran dana oleh para pemilik perusahaan; (f) Penerimaan pinjaman jangka panjang dan jangka pendek yang diperoleh dari Bank atau pihak lain; (g) Pinjaman yang dijamin dengan hipotek atas aktiva tetap atau aktiva tak lancar; (h) Penjualan piutang dengan jalan penjualan biasa/dengan "factoring" (penjualan dengan cara penjualan faktur, pemberian kredit, diserahkan pada lembaga keuangan).

\subsection{Efisiensi Modal Kerja}

Manajemen atau pengelolaan modal kerja merupakan hal yang sangat penting agar kelangsungan usaha sebuah perusahaan dapat dipertahankan (Hanafi, 2015). Kesalahan atau kekeliruan dalam pengelolaan modal kerja akan menyebabkan buruknya kondisi keuangan perusahaan sehingga kegiatan perusahaan dapat terhambat atau terhenti sama sekali. Adanya kesalahan atau kekeliruan dalam pengelolaan modal kerja dapat menimbulkan kelebihan atau kekurangan dalam penyediaan modal kerja (Tunggal, 2015). Adanya kelebihan modal kerja dalam sebuah perusahaan dapat disebabkan oleh : (a) Pengeluaran obligasi/saham dalam jumlah yang lebih dari yang diperlukan; (b) Penjualan aktiva tak lancar yang tak diganti; (c) Terjadinya laba operasi yang tidak digunakan untuk pembayaran dividen, untuk pembelian aktiva tetap atau untuk tujuan lain yang serupa; (d) Konversi atau perubahan aktiva tetap ke dalam modal kerja. Konversi perubahan bentuk yang tak disertai dengan penggantian dari aktiva tetap ke dalam modal kerja dengan jalan proses depresiasi, deplesi dan amortisasi; (e) Karena akumulasi atau penimbunan sementara dari berbagai dana yang disediakan untuk investasi-investasi dan sebagainya.

Sedangkan terjadinya kekurangan modal kerja menurut Wijaya (2013) dapat disebabkan oleh : (1) kerugian usaha; (2) kerugian luar biasa; (3) kebijakan dividen yang kurang baik; (4) kenaikan tingkat harga umum. Kerugian usaha, antara lain diakibatkan oleh: (a) Volume penjualan yang tidak mencukupi, jadi terlalu kecil untuk dapat menutup; (b) biaya perusahaan; (c) Penurunan harga jual yang disebabkan karena persaingan tanpa 


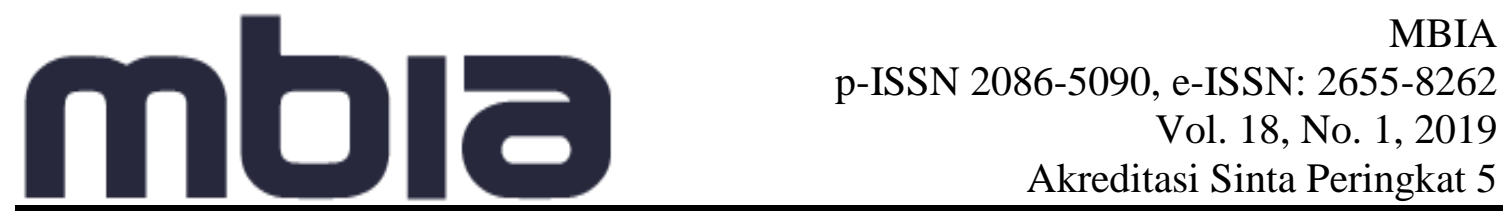

adanya penurunan dalam harga pokok penjualan; (d) Terlalu banyak piutang yang tidak dapat ditagih. d Kenaikan biaya yang tidak diimbangi dengan bertambahnya penjualan atau pendapatan; (e) Bertambahnya biaya, sedang penjualan atau pendapatan menurun.

Kerugian luar biasa adalah kerugian yang tidak disebabkan karena operasi rutin perusahaan. Kebijakan dividen yang kurang baik terjadi karena perusahaan memutuskan membayarkan dividen meskipun kondisi keuangan perusahaan tidak memungkinkan untuk memberikan dividen pada para pemegang saham. Kekurangan modal kerja kadang terjadi karena dilakukannya investasi dari aktiva lancar untuk memperoleh aktiva tak lancar. Hal ini terjadi apabila suatu aktiva yang tua harus diganti dengan yang baru atau apabila dibeli aktiva tetap lain yang baru atau karena pembelian saham perusahaan lain sebagai investasi.

Kekurangan modal kerja dapat disebabkan karena kenaikan harga yang memerlukan investasi jumlah rupiah yang telah banyak untuk memelihara kuantitas persediaan dan aktiva pada tingkat fisik yang sama dan untuk membiayai penjualan kredit pada tingkat penjualan yang sama. Indikasi pengelolaan modal kerja yang baik adalah adanya efisiensi modal kerja yang dilihat dari perputaran modal kerja (Husnan, 2013) yang dimulai dari aset kas diinvestasikan dalam komponen modal kerja sampai saat kembali menjadi kas. Makin pendek periode perputarannya, makin cepat perputarannya sehingga perputaran modal kerja makin tinggi dan perusahaan makin efisiens yang pada akhirnya rentabilitas semakin tinggi.

\section{Metodologi Penelitian}

Penelitian ini dilakukan pada PT Mayora yang beralamat di jalan Palembang Betung KM 18 Kecamatan Talang Kelapa Banyuasin. Jenis data yang dipakai adalah data primer, yaitu data yang penulis kumpulkan langsung dari PT Matora Tbk Cabang Banyuasin, yaitu berupa data-data tentang berdiri PT Mayora, Tbk, data tentang struktur organisasi dan pembagian tugas, serta laporan keuangan perusahaan PT Mayora. Sumber data yang digunakan dalam penelitian ini adalah laporan keuangan perusahaan PT Mayora.

Penggunaan analisis deskriptif ini ditujukan untuk mengetahui gambaran kondisi efisiensi modal kerja, likuiditas, dan solvabilitas terhadap profitabilitas melalui return on investment perusahaan yang dikomparasikan secara eksternal, yaitu melibatkan satu perusahaan yang dibandingkan dengan kondisi rata-rata dari seluruh objek penelitian.

Metode analisis data yang digunakan dalam penelitian ini adalah analisis regresi berganda. Regresi berganda berguna untuk meramalkan pengaruh dua variabel prediktor atau lebih terhadap satu variabel kriterium atau untuk membuktikan ada atau tidaknya hubungan fungsional antara dua buah variabel bebas (X) atau lebih dengan sebuah variabel terikat (Y) (Usman, 2013). Analisis regresi berganda dalam penelitian ini digunakan untuk mengetahui pengaruh Efisiensi Modal kerja dan Likuiditas terhadap Profitabilitas PT Mayora Tbk. Formulasi persamaan regresi berganda sendiri adalah sebagai berikut:

$\mathrm{Y}=\mathrm{a}+\mathrm{b}_{1} \mathrm{X}_{1}+\mathrm{b}_{2} \mathrm{X}_{2}+\mathrm{e}$

Dimana:

Y : Profitabilitas 
a : Bilangan Konstanta

b1 - b3 : Koefisien Regresi

X1 : Efisiensi Modal Kerja

$\mathrm{X} 2$ : Likuiditas

e : Variabel Pengganggu

\section{Hasil dan Pembahasan}

Penelitian ini dilakukan pada PT Mayora Indah Tbk selama periode tahun 2017 - 2016 menggunakan data tahunan. Sebelum membahas pengaruh efisiensi modal kerja dan likuiditas terhadap profitabilitas, terlebih dahulu akan dibahas perkembangan efisiensi modal kerja, likuiditas, dan profitabilitas perusahaan selama periode 2017 - 2016. Efisiensi Modal Kerja dan Likuiditas terhadap Profitabilitas pada PT Mayora Indah Tbk.

Efisiensi modal kerja diukur dari rasio operating profit terhadap current assets. Semakin besar efisiensi modal kerja dari suatu perusahaan menunjukkan ketersediaan dana yang dapat digunakan perusahaan untuk investasi lain yang lebih menguntungkan semakin tinggi. Dari hasil penelitian diperoleh gambaran efisiensi modal kerja pada PT Mayora Indah Tbk sebagai berikut.

Pada tabel 4.1 dapat digambarkan bahwa pada tahun 2007 Operating Profit pada PT Mayora Indah Tbk adalah 100,696 dan Current Asset sebesar 601,233. Sehingga modal kerja yang efisien pada PT Mayora Indah Tbk adalah 16.75\%. Pada tahun 2008 Operating Profit pada PT Mayora Indah Tbk adalah 151,799 dan Current Asset sebesar 683,149 Sehingga modal kerja yang efisien pada PT Mayora Indah Tbk adalah 22.22\%. Pada tahun ini modal kerja mengalami peningkatan karena modal kerja digunakan lebih efisien dari sebelumnya, terlihat dari tabel 4.1 Operating profit dan Current Asset nya pun mengalami peningkatan.

Tabel 4.1 Perkembangan Efisiensi Modal Kerja Pada PT Mayora Indah Tbk

\begin{tabular}{|l|l|l|l|l|}
\hline Tahun & \multicolumn{1}{|c|}{ Operating profit } & Current asset & \multicolumn{1}{|c|}{ Efisiensi } & Perkembangan \\
\hline 2007 & 100,696 & 601,233 & $16.75 \%$ & \\
\hline 2008 & 151,799 & 683,149 & $22.22 \%$ & $5.47 \%$ \\
\hline 2009 & 150,065 & 679,771 & $22.08 \%$ & $-0.14 \%$ \\
\hline 2010 & 130,632 & 637,641 & $20.49 \%$ & $-1.59 \%$ \\
\hline 2011 & 93,535 & 675,637 & $13.84 \%$ & $-6.64 \%$ \\
\hline 2012 & 170,905 & 796,223 & $21.46 \%$ & $7.62 \%$ \\
\hline 2013 & 238,713 & $1,043,843$ & $22.87 \%$ & $1.40 \%$ \\
\hline 2014 & 345,420 & $1,684,853$ & $20.50 \%$ & $-2.37 \%$ \\
\hline 2015 & 613,187 & $1,750,424$ & $35.03 \%$ & $14.53 \%$ \\
\hline 2016 & 537,796 & $1,996,532$ & $26.94 \%$ & $-8.09 \%$ \\
\hline & Rata-Rata & & $22.22 \%$ & $1.13 \%$ \\
\hline
\end{tabular}

Sumber : data diolah dari hasil penelitian, 2018

Pada tahun ini PT Mayora Indah Tbk mengalami perkembangan modal kerja yang efisien sebesar 5.47\% Hal ini dikarenakan Perusahaan mampu mengoperasikan modal kerjanya secara efisien karena tidak ada kesulitan dalam memperoleh bahan baku maupun suplai 


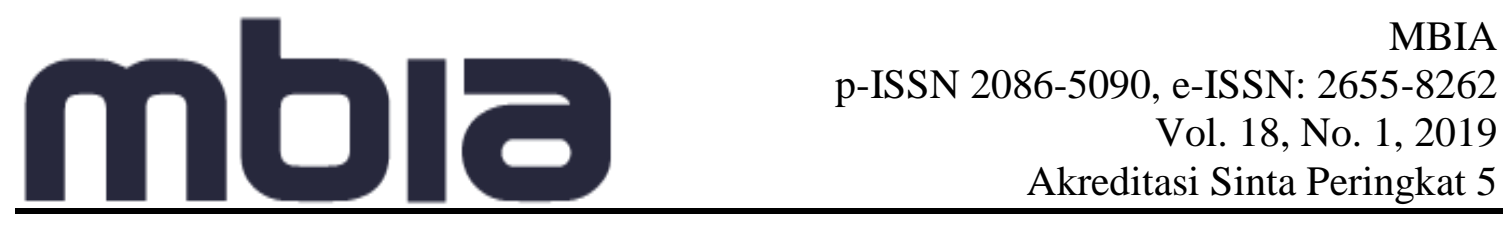

yang dibutuhkan. Pada tahun 2009 Operating Profit pada PT Mayora Indah Tbk adalah 150,065 dan Current Asset sebesar 679,771 Sehingga modal kerja yang efisien pada PT Mayora Indah Tbk adalah $22.08 \%$. Pada tahun ini modal kerja mengalami penurunan karena modal kerja tidak digunakan secara efisien dari tahun sebelumnya, terlihat dari tabel 4.1 Operating profit mengalami penurunan dan Current Asset nya mengalami peningkatan. Pada tahun ini PT Mayora Indah Tbk mengalami penurunan modal kerja yang efisien sebesar $0.14 \%$ Hal ini dikarenakan modal kerja yang didapat digunakan untuk membeli surat-surat berharga dan untuk berinvestasi.

Sama halnya dengan tahun 2009 PT Mayora Indah Tbk mengalami penurunan modal kerja yang efisien pada tahun 2010 dan tahun 2011. Pada tahun 2010 Operating Profit pada PT Mayora Indah Tbk adalah 130,632 dan Current Asset sebesar 637,641 Sehingga modal kerja yang efisien pada PT Mayora Indah Tbk adalah 20.49\%. Pada tahun ini modal kerja mengalami penurunan karena modal kerja tidak digunakan secara efisien dari tahun sebelumnya, terlihat dari tabel 4.1 Operating profit dan Current Asset nya pun mengalami penurunan. Pada tahun ini PT Mayora Indah Tbk mengalami penurunan modal kerja yang efisien sebesar 1.59\% Sedangkan pada tahun 2011 Operating Profit pada PT Mayora Indah Tbk adalah 93,535 dan Current Asset sebesar 675,637 Sehingga modal kerja yang efisien pada PT Mayora Indah Tbk adalah 13.84\%. Pada tahun ini modal kerja mengalami penurunan cukup banyak daripada tahun sebelumnya karena modal kerja tidak digunakan secara efisien dari tahun sebelumnya, terlihat dari tabel 4.1 Operating profit mengalami penurunan dan Current Asset mengalami peningkatan. Pada tahun ini PT Mayora Indah Tbk mengalami penurunan modal kerja yang efisien sebesar 6.64\% Pada tahun 2004 dan 2011 modal kerja belum dilakukan secara efisien sehingga modal kerjanya menurun karena perusahaan masih melakukan investasi dan belum mendapatkan keuntungan lebih dari berinvestasi tersebut.

Setelah selama 3 tahun mengalami penurunan modal kerja yang kurang efisien, pada tahun 2012 dan 2013 kembali mengalami peningkatan dalam modal kerja yang efisien. Pada tahun 2012 Operating Profit pada PT Mayora Indah Tbk adalah 170,905 dan Current Asset sebesar 796,223 Sehingga modal kerja yang efisien pada PT Mayora Indah Tbk adalah $21.46 \%$. Pada tahun ini modal kerja mengalami peningkatan karena modal kerja digunakan lebih efisien dari sebelumnya, terlihat dari tabel 4.1 Operating profit dan Current Asset nya pun mengalami peningkatan. Pada tahun ini PT Mayora Indah Tbk mengalami perkembangan modal kerja yang efisien sebesar $7.62 \%$ Hal ini dikarenakan perusahaan sudah mendapatkan keuntungan dari berinvestasi sebelumnya. Pada tahun 2013 Operating Profit pada PT Mayora Indah Tbk adalah 238,713 dan Current Asset sebesar 1,043,843 Sehingga modal kerja yang efisien pada PT Mayora Indah Tbk adalah 22.87\%. Pada tahun ini modal kerja mengalami peningkatan karena modal kerja digunakan lebih efisien dari sebelumnya, terlihat dari tabel 4.1 Operating profit dan Current Asset nya pun mengalami peningkatan. Pada tahun ini PT Mayora Indah Tbk mengalami perkembangan modal kerja yang efisien sebesar $1.40 \%$ hal ini dikarenakan kas yang didapat ditahun sebelumnya lebih besar sehingga kas tersebut di efesienkan untuk membeli bahan baku.

Pada tahun 2014 PT Mayora Indah Tbk mengalami penurunan modal kerja. Operating Profit pada PT Mayora Indah Tbk adalah 354,420 dan Current Asset sebesar 1,684,853 
Sehingga modal kerja yang efisien pada PT Mayora Indah Tbk adalah 20.50\%. Pada tahun ini modal kerja mengalami penurunan cukup banyak daripada tahun sebelumnya karena modal kerja tidak digunakan secara efisien dari tahun sebelumnya, terlihat dari tabel 4.1 Operating profit dan Current Asset nya pun mengalami peningkatan. Pada tahun ini PT Mayora Indah Tbk mengalami penurunan modal kerja yang efisien sebesar $2.37 \%$ hal ini dikarenakan naiknya harga bahan baku sehingga kas yang harus dikelurakan harus lebih banyak. Sedangkan pada tahun 2015 Operating Profit pada PT Mayora Indah Tbk adalah 613,187 dan Current Asset sebesar 1,750,424 Sehingga modal kerja yang efisien pada PT Mayora Indah Tbk adalah 35,03\%. Pada tahun ini modal kerja mengalami peningkatan karena modal kerja digunakan lebih efisien dari sebelumnya, terlihat dari tabel 4.1 Operating profit dan Current Asset nya pun mengalami peningkatan. Pada tahun ini PT Mayora Indah Tbk mengalami perkembangan modal kerja yang efisien sebesar $14.53 \%$ hal ini dikarenakan perusahaan mendapatkan keuntungan atau kas lebih dari berinvestasi.

Pada tahun 2016 PT Mayora Indah Tbk kembali mengalami penurunan modal kerja. Operating Profit pada PT Mayora Indah Tbk adalah 537,796 dan Current Asset sebesar 1,996,532 Sehingga modal kerja yang efisien pada PT Mayora Indah Tbk adalah 26.94\%. Pada tahun ini modal kerja mengalami penurunan karena modal kerja tidak digunakan secara efisien dari tahun sebelumnya, terlihat dari tabel 4.1 Operating profit mengalami penurunan dan Current Asset mengalami peningkatan. Pada tahun ini PT Mayora Indah Tbk mengalami penurunan modal kerja yang efisien sebesar $8.09 \%$ hal ini dikarenakan modal kerja yang didapat digunakan untuk melunasi hutang yang sudah jatuh tempo. Maka dapat disimpulkan, operating profit yang diperoleh PT Mayora Indah Tbk cenderung menurun selama periode tahun 2007 hingga tahun 2009, namun pada tahun 2012 hingga tahun 2013 terus mengalami peningkatan. Kemudian current assets yang dimiliki PT Mayora Indah Tbk cenderung fluktuatif, hanya saja semenjak tahun 2014 terus mengalami peningkatan hingga tahun 2016. Secara rata-rata efisiensi modal kerja pada PT Mayora Indah Tbk sebesar 22,22\% setiap tahunnya dengan rata-rata peningkatan sebesar $1,13 \%$ setiap tahunnya.

Likuiditas diukur dari rasio current assets terhadap current liabilities. Semakin tinggi likuiditas menunjukkan peningkatan kemampuan perusahaan untuk memenuhi kewajiban jangka pendeknya. Dari hasil penelitian diperoleh gambaran likuiditas pada PT Mayora Indah Tbk sebagai berikut:

Tabel 4.2 Perkembangan Likuiditas Pada PT Mayora Indah Tbk

\begin{tabular}{|l|l|l|l|l|}
\hline Tahun & Cuurent Liabilities & Current asset & \multicolumn{1}{|c|}{ Likuiditas } & Perkembangan \\
\hline 2007 & 131,618 & 601,233 & $456.80 \%$ & - \\
\hline 2008 & 114,014 & 683,149 & $599.18 \%$ & $142.38 \%$ \\
\hline 2009 & 69,247 & 679,771 & $981.66 \%$ & $382.48 \%$ \\
\hline 2010 & 124,850 & 637,641 & $510.73 \%-$ & $470.94 \%$ \\
\hline 2011 & 191,029 & 675,637 & $353.68 \%-$ & $157.04 \%$ \\
\hline 2012 & 203,673 & 796,223 & $390.93 \%$ & $37.25 \%$ \\
\hline 2013 & 356,123 & $1,043,843$ & $293.11 \%-$ & $97.82 \%$ \\
\hline 2014 & 769,800 & $1,684,853$ & $218.87 \%-$ & $74.24 \%$ \\
\hline 2015 & 764,230 & $1,750,424$ & $229.04 \%$ & $10.18 \%$ \\
\hline
\end{tabular}




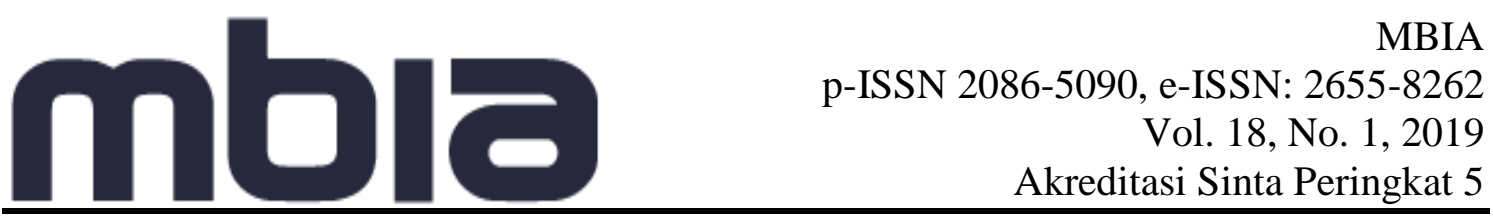

\begin{tabular}{|l|l|l|l|l|}
\hline 2016 & 836,905 & $1,996,532$ & $238.56 \%$ & $9.52 \%$ \\
\hline & Rata-Rata & & $427.26 \%$ & $-24.25 \%$ \\
\hline
\end{tabular}

Sumber : data diolah dari hasil penelitian, 2018

Pada Tabel 4.2 dapat dikatakan bahwa pada tahun 2007 Current Asset yang dimiliki oleh PT Mayora Indah Tbk adalah 601,233 dan Current Liabilities sebesar 131,618. Maka Likuiditas pada PT Mayora Indah Tbk adalah 456.80\% Pada tahun 2008 dan 2009 Likuiditas pada PT Mayora Indah Tbk mengalami peningkatan. Pada tahun 2008 Current Asset yang dimiliki oleh PT Mayora Indah Tbk adalah 683,149 dan Current Liabilities sebesar 114,014. Maka Likuiditas pada PT Mayora Indah Tbk mengalami peningkatan menjadi 599.18\%. Current Asset mengalami peningkatan sedangkan Current Liabilities mengalami penurunan. Likuiditas pada PT Mayora mengalami perkembangan sebesar $142.38 \%$ hal ini dikarenakan perusahaan mampu membayar kewajiban jangka pendeknya. Sedangkan pada tahun 2009 Current Asset yang dimiliki oleh PT Mayora Indah Tbk adalah 679.771 dan Current Liabilities sebesar 69,247. Maka Likuiditas pada PT Mayora Indah Tbk mengalami peningkatan menjadi $981.66 \%$.

Current Asset dan Current Liabilities mengalami penurunan Likuiditas pada PT Mayora mengalami perkembangan sebesar $384.48 \%$ hal ini dapat disebabkan karena telah mampu membayar hutang jangka pendeknya lebih besar dari tahun sebelumnya. Pada tahun 2010 dan 2011 Likuiditas mengalami penurunan. Dapat dilihat dari table tersebut pada tahun 2010 Current Asset yang dimiliki oleh PT Mayora Indah Tbk adalah 637,641 dan Current Liabilities sebesar 124,850. Maka Likuiditas pada PT Mayora Indah Tbk mengalami penurunan menjadi $510.73 \%$. Current Asset mengalami penurunan sedangkan Current Liabilities mengalami peningkatan. Likuiditas pada PT Mayora mengalami perkembangan sebesar 470.94\% Sedangkan pada tahun 2011 Current Asset yang dimiliki oleh PT Mayora Indah Tbk adalah 675,637 dan Current Liabilities sebesar 191,029. Maka Likuiditas pada PT Mayora Indah Tbk mengalami penurunan menjadi 353.68\%.

Current Asset dan Current Liabilities mengalami peningkatan. Likuiditas pada PT Mayora mengalami penurunan sebesar $157.04 \%$ hal ini dikarenakan perusahaan mendapatkan keuntungan dari berinvestasi sehingga perusahaan mampu untuk memenuhi kewajiban jangka pendeknya. Pada tahun 2011 Current Asset yang dimiliki oleh PT Mayora Indah Tbk adalah 796,223 dan Current Liabilities sebesar 203,673. Maka Likuiditas pada PT Mayora Indah Tbk mengalami peningkatan menjadi 390.93\%. Current Asset dan Current Liabilities mengalami peningkatan. Likuiditas pada PT Mayora mengalami perkembangan sebesar 37.25\% Hal ini dikarenakan kas yang dimiliki oleh perusahaan digunakan untuk berinvestasi sehingga perusahaan belum mampu untuk memenuhi kewajiban jangka pendeknya. Pada tahun 2012 dan 2013 Likuiditas pada PT Mayora Indah Tbk kembali mengalami penurunan. Pada tahun 2012 Current Asset yang dimiliki oleh PT Mayora Indah Tbk adalah 1,043,843 dan Current Liabilities sebesar 356,123. Maka Likuiditas pada PT Mayora Indah Tbk mengalami penurunan menjadi $353.68 \%$. Current Asset dan Current Liabilities mengalami peningkatan. Likuiditas pada PT Mayora mengalami penurunan sebesar 97.82\% sedangkan pada tahun 2013 Current Asset yang dimiliki oleh PT Mayora Indah Tbk adalah 1,684,853 dan Current Liabilities 
sebesar 796,800. Maka Likuiditas pada PT Mayora Indah Tbk mengalami penurunan menjadi $218,87 \%$.

Current Asset dan Current Liabilities mengalami peningkatan. Likuiditas pada PT Mayora mengalami penurunan sebesar $74.24 \%$ Hal ini dikarenakan perusahaan mendapatkan keuntungan, sehingga kas yang didapat mampu untuk melunasi kewajibankewajiban jangka pendeknya. Beda halnya dengan tahun sebelumnya, pada tahun 2013 dan 2014 likuiditas mengalami peningkatan. Pada tahun 2015 Current Asset yang dimiliki oleh PT Mayora Indah Tbk adalah 1,750,424 dan Current Liabilities sebesar 764,230. Maka Likuiditas pada PT Mayora Indah Tbk mengalami peningkatan menjadi 229.04\%. Current Asset mengalami peningkatan sedangkan Current Liabilities mengalami penurunan. Likuiditas pada PT Mayora mengalami perkembangan sebesar $10.18 \%$ Pada tahun 2016 Current Asset yang dimiliki oleh PT Mayora Indah Tbk adalah 1,996,532 dan Current Liabilities sebesar 836.905. Maka Likuiditas pada PT Mayora Indah Tbk mengalami peningkatan menjadi 238.56\%. Current Asset dan Current Liabilities mengalami peningkatan. Likuiditas pada PT Mayora mengalami perkembangan sebesar 10.18\% Namun jika dilihat perusahan pada tahun 2015 juga mengalami peningkatan

Hal ini berbanding terbalik dengan teori menurut Musdholifah dan Triambodo (2016) mengungkapkan bahwa Kemampuan memperoleh laba (profitabilitas) berbanding terbalik dengan likuiditas. Hal ini dikarenakan kas yang dimiliki perusahaan digunakan untuk pembelian bahan baku sehingga kas pada perusahaan belum mampi memenuhi lewajiban jangka pendeknya. Maka dapat disimpulkan bahwa current liabilities PT Mayora Indah Tbk cenderung terus mengalami peningkatan semenjak hingga tahun 2013, demikian juga current assets yang dimiliki PT Mayora Indah Tbk terus mengalami peningkatan semenjak tahun 2014. Secara rata-rata likuiditas pada PT Mayora Indah Tbk sebesar 427,26\% setiap tahunnya dengan rata-rata penurunan sebesar 24,25\% setiap tahunnya.

Profitabilitas diproksi dari return on investment, yaitu rasio operating profit terhadap total assets yang dimiliki perusahaan. Rasio ini menunjukkan kemampuan manajemen dalam mengelola assets untuk menghasilkan keuntungan bagi perusahaan. Berikut perkembangan profitabilitas yang diperoleh PT Mayora Indah Tbk selama periode tahun 2007-2015:

Tabel 4.3 Perkembangan Profitabilitas PT Mayora Indah Tbk

\begin{tabular}{|l|l|l|l|l|}
\hline Tahun & Operating & Total asset & Profitabilitas & Perkembangan \\
\hline 2007 & 100,696 & $1,324,990$ & $7.60 \%$ & \\
\hline 2008 & 151,799 & $1,332,375$ & $11.39 \%$ & $3.79 \%$ \\
\hline 2009 & 150,065 & $1,283,833$ & $11.69 \%$ & $0.30 \%$ \\
\hline 2010 & 130,632 & $1,280,640$ & $10.20 \%$ & $-1.49 \%$ \\
\hline 2011 & 93,535 & $1,459,970$ & $6.41 \%$ & $-3.79 \%$ \\
\hline 2012 & 170,905 & $1,553,377$ & $11.00 \%$ & $4.60 \%$ \\
\hline 2013 & 238,713 & $1,893,175$ & $12.61 \%$ & $1.61 \%$ \\
\hline 2014 & 345,420 & $2,922,998$ & $11.82 \%$ & $-0.79 \%$ \\
\hline 2015 & 613,187 & $3,246,499$ & $18.89 \%$ & $7.07 \%$ \\
\hline
\end{tabular}




\begin{tabular}{|c|c|c|c|c|}
\hline \multirow[t]{2}{*}{2016} & 537,796 & $3,640,747$ & $14.77 \%$ & $-4.12 \%$ \\
\hline & Rata-Rata & & $11.64 \%$ & $0.80 \%$ \\
\hline
\end{tabular}

Sumber : data diolah dari hasil penelitian, 2018

Pada tabel 4.3 dapat digambarkan bahwa pada tahun 2007 Operating Profit pada PT Mayora Indah Tbk adalah 100,696 dan Total Asset sebesar 1,324,990. Maka Profitabilitas pada PT Mayora Indah Tbk adalah 7.60\% Pada tahun 2008 Operating Profit pada PT Mayora Indah Tbk adalah 151,799 dan Total Asset sebesar 1,332,375. Maka Profitabilitas pada PT Mayora Indah Tbk meningkat menjadi 11.39\% Operating Profit dan Total Asset mengalami peningkatan. Perkembangan profitabilitas PT Mayora Indah Tbk pada tahun 2008 adalah $3.79 \%$ hal ini dikarenakan perusahaan mengalami keuntungan dari penjualan. Begitupun pada tahun 2009 Operating Profit pada PT Mayora Indah Tbk adalah 150,065 dan Total Asset sebesar 1,283,833. Maka Profitabilitas pada PT Mayora Indah Tbk meningkat menjadi 11.69\% Operating Profit dan Total Asset mengalami penurunan. Perkembangan profitabilitas PT Mayora Indah Tbk pada tahun 2003 adalah $0.30 \%$ perusahaan kembali mengdapatkan keuntungan yang diapat dari hasil penjualan.

Sedangkan pada tahun 2010 dan 2011 Profitabilitas mengalami penurunan. Pada tahun 2010 Operating Profit pada PT Mayora Indah Tbk adalah 130,632 dan Total Asset sebesar 1,280,640. Maka Profitabilitas pada PT Mayora Indah Tbk menurun menjadi 10.20\% Operating Profit dan Total Asset mengalami penurunan. Penurunan Profitabilitas PT Mayora Indah Tbk pada tahun 2010 sebesar 1.49\% Sedangkan pada 2011 Operating Profit pada PT Mayora Indah Tbk adalah 93,535 dan Total Asset sebesar 1,459,970. Maka Profitabilitas pada PT Mayora Indah Tbk menurun menjadi $6.41 \%$ Operating Profit mengalami penurunan sedangkan Total Asset mengalami peningkatan. Penurunan Profitabilitas PT Mayora Indah Tbk pada tahun 2005 sebesar 3.79\% Hal ini dikarenakan kas pada perusahaan digunakan untuk berinvestasi dan belum mendapatkan keuntungan dari investasi tersebut.

Pada tahun 2013 dan 2014 Profitabilitas PT Mayora Indah Tbk mengalami peningkatan. Pada tahun 2013 Operating Profit pada PT Mayora Indah Tbk adalah 170,905 dan Total Asset sebesar 1,553,377. Maka Profitabilitas pada PT Mayora Indah Tbk meningkat menjadi $11.00 \%$ Operating Profit dan Total Asset mengalami peningkatan. Perkembangan profitabilitas PT Mayora Indah Tbk pada tahun 2012 adalah 4.60\% Sedangkan pada tahun 2013 Operating Profit pada PT Mayora Indah Tbk adalah 238,713 dan Total Asset sebesar 1,893,175. Maka Profitabilitas pada PT Mayora Indah Tbk meningkat menjadi 12.61\% Operating Profit dan Total Asset mengalami peningkatan. Perkembangan profitabilitas PT Mayora Indah Tbk pada tahun 2013 adalah 1.61\% Hal ini dikarenakan mendapatkan keuntungan dari berinvestasi di tahun sebelumnya.

Pada tahun 2014 Likuiditas pada PT Mayora Indah Tbk kembali mengalami penurunan. Operating Profit pada PT Mayora Indah Tbk adalah 354,420 dan Total Asset sebesar 2,92,998. Maka Profitabilitas pada PT Mayora Indah Tbk menurun menjadi $11.82 \%$ Operating Profit dan Total Asset mengalami peningkatan. Penurunan Profitabilitas PT Mayora Indah Tbk pada tahun 2014 sebesar $0.79 \%$ Hal ini dikarenakan pembelian bahan baku dan mesin-mesin produksi yang mengurangi kas pada perusahaan. Pada tahun 2015 Operating Profit pada PT Mayora Indah Tbk adalah 613,187 dan Total Asset sebesar 


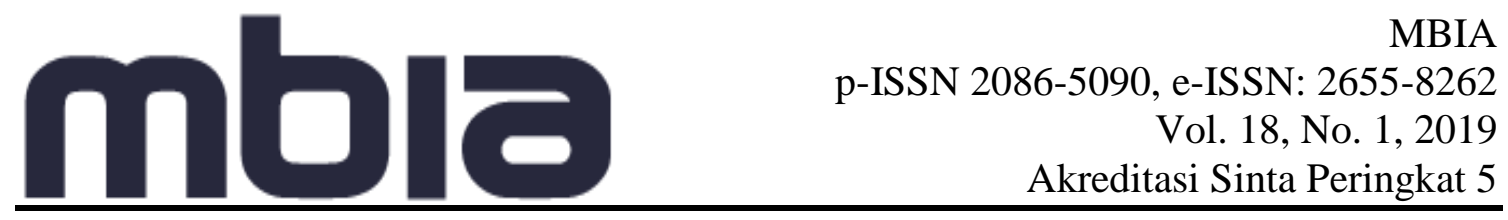

3,246,499. Maka Profitabilitas pada PT Mayora Indah Tbk meningkat menjadi $18.89 \%$ Operating Profit dan Total Asset mengalami peningkatan. Perkembangan profitabilitas PT Mayora Indah Tbk pada tahun 2015 adalah 7.07\%

Namun dilihat dari segi Likuiditasnya atau kemampuan memenuhi jangka pendeknya juga meningkat teori menurut Musdholifah dan Triambodo (2016) mengungkapkan bahwa Kemampuan memperoleh laba (profitabilitas) berbanding terbalik dengan likuiditas. Hal ini dikarenakan penjualan yang terus meningkat menyebabkan keuntungan lebih dari tahun sebelumnya. Pada tahun 2016 Profitabilitas pada PT Mayora Indah Tbk kembali mengalami penurunan. Operating Profit pada PT Mayora Indah Tbk adalah 537,796 dan Total Asset sebesar 3,640,747. Maka Profitabilitas pada PT Mayora Indah Tbk menurun menjadi $14.77 \%$ Operating Profit mengalami peningkatan sedangkan Total Asset mengalami penurunan. Penurunan Profitabilitas PT Mayora Indah Tbk pada tahun 2016 sebesar $4.12 \%$ Hal ini dikarenakan adanya kerugian karena piutang tidak kembali. Maka dapat disimpulkan total assets yang dimiliki perusahaan mengalami peningkatan semenjak tahun 2011. Sementara operating profit yang diperoleh PT Mayora Indah Tbk cenderung menurun selama periode tahun 2009 hingga tahun 2010, namun pada tahun 2013 hingga tahun 2014 terus mengalami peningkatan. Secara rata-rata profitabilitas pada PT Mayora Indah Tbk sebesar 11,64\% setiap tahunnya dengan rata-rata peningkatan sebesar $0,80 \%$ setiap tahunnya.

Pada tabel 4.4 dapat dilihat nilai probabilitas (asymp.sig.) yang diperoleh dari uji Kolmogorov-Smirnov sebesar 0,826. Karena nilai probabilitas pada uji KolmogorovSmirnov masih lebih besar dari tingkat kekeliruan 5\% (0.05), maka disimpulkan bahwa model regressi berdistribusi normal.

Tabel 4.4 Hasil Pengujian Asumsi Normalitas

One-Sample Kolmogorov-Smirnov Test

\begin{tabular}{|lcr|}
\hline & & Unstandardiz ed Residual \\
\hline Normal Parameters & mean & 10 \\
& Std. Deviation & .00000000 \\
Most Extreme & absoulte & .55608933 \\
Differences $\quad$ positive & .198 \\
& negative & .198 \\
Kolmogorov-Smirnov Z & -.111 \\
Asy mp. Sig. (2-tailed) & .627 \\
\hline
\end{tabular}

a. Test distribution is Normal.

b. Calculated $f$ rom data.

ROI Berdasarkan nilai VIF yang diperoleh seperti terlihat pada tabel 4.5 menunjukkan tidak ada korelasi yang cukup kuat antara sesama variabel bebas, dimana nilai VIF dari kedua variabel bebas lebih kecil dari 10 dan dapat disimpulkan tidak terdapat multikolinieritas diantara kedua variabel bebas.

Tabel 4.5 Hasil Pengujian Asumsi Multikolinieritas

Coefficients a 


\begin{tabular}{|c|c|c|}
\hline Model & \multicolumn{2}{|c|}{ Colinieritas statistic } \\
\hline 1 & Tolerance & VIF \\
\hline $\begin{array}{l}\text { RWC } \\
\text { CR }\end{array}$ & $\begin{array}{l}.941 \\
941\end{array}$ & $\begin{array}{l}1.062 \\
1.062\end{array}$ \\
\hline
\end{tabular}

a. Dependent Variable:

Pada tabel 4.6 berikut dapat dilihat nilai signifikansi masing-masing koefisien korelasi variabel bebas terhadap nilai absolut dari residual(error).

Tabel 4.6 Hasil Pengujian Asumsi Heteroskedastisitas Correlations

\begin{tabular}{|ll|l|r|}
\hline \multicolumn{2}{|l|}{} & Absolute error \\
\hline Spearman's rho & RWC & Correlation Coef f icient & -.164 \\
& & Sig. (2-tailed) & .651 \\
& & N & 10 \\
\hline \multirow{2}{*}{ CR } & Correlation Coef f icient & -.394 \\
& Sig. (2-tailed) & .260 \\
& N & 10 \\
\hline
\end{tabular}

Berdasarkan hasil korelasi yang diperoleh seperti dapat dilihat pada tabel 4.6 diatas memberikan suatu indikasi bahwa residual (error) yang muncul dari persamaan regresi mempunyai varians yang sama (tidak terjadi heteroskedastisitas), dimana nilai signifikansi (sig) dari masing-masing koefisien korelasi kedua variabel bebas dengan nilai absolut error $(0,651$ dan 0,260) masih lebih besar dari 0,05.

Berdasarkan hasil pengolahan diperoleh nilai statistik Durbin-Watson $(\mathrm{DW})=1,925$, sementara dari tabel $\mathrm{d}$ untuk jumlah variabel bebas $=2$ dan jumlah pengamatan $n=10$ diperoleh batas bawah nilai tabel $(\mathrm{dL})=0,697$ dan batas atasnya $(\mathrm{dU})=1,641$. Karena nilai Durbin-Watson model regressi $(1,925)$ berada diantara dU $(1,641)$ dan 4-dU $(2,359)$, yaitu daerah tidak ada autokorelasi, maka dapat disimpulkan tidak terjadi autokorelasi pada model regressi. Terdapat Autokorelasi Positif Terdapat Autokorelasi Negatif Tidak Terdapat Autokorelasi Tidak Ada Keputusan Tidak Ada Keputusan 0 dL =0,697 dU $=1,6414-\mathrm{dU}=2,3594-\mathrm{dL}=3,303 \mathrm{D}-\mathrm{W}=1,925$

Tabel 4.7 Nilai Durbin-Watson Untuk Uji Autokorelasi Model Summary ${ }^{b}$.

\begin{tabular}{|c|c|l|l|l|l|}
\hline Model & $\mathrm{R}$ & R Square & $\begin{array}{c}\text { Adjusted R } \\
\text { Square }\end{array}$ & $\begin{array}{c}\text { Std. Error } \\
\text { of the } \\
\text { Estimate }\end{array}$ & DurbinWatson \\
\hline 1 & $987 \mathrm{a}$. & 975 & .967. & 63055 & 1.925 \\
\hline
\end{tabular}

a. Predictors: (Constant), CR, RWC

b. Dependent Variable: ROI

Untuk mengetahui bentuk hubungan linier dari efisiensi modal kerja dan likuiditas digunakan analisis regresi linier berganda. Dalam hal ini, parameter model persamaan regresi taksiran dicari dengan menggunakan metode kuadrat terkecil yang memiliki sifat Best Linier Unbiased Estimator (BLUE). Analisis regresi berganda digunakan untuk 


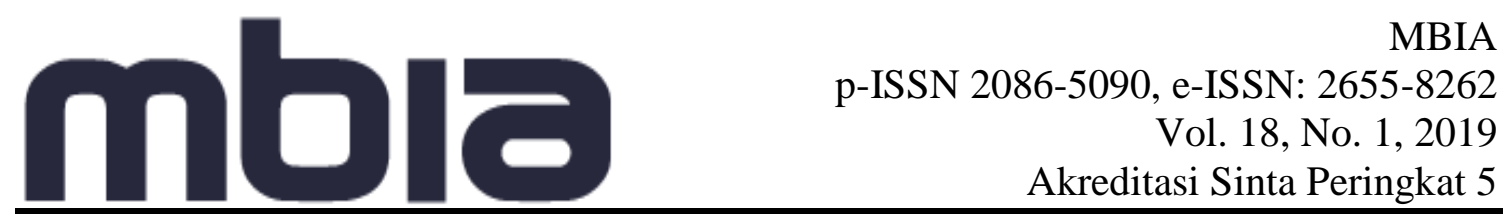

menguji pengaruh variabel independen yaitu efisiensi modal kerja dan likuiditas terhadap profitabilitas. Estimasi model regresi linier berganda ini menggunakan software SPSS.22 dan diperoleh hasil output sebagai berikut :

Tabel 4.8 Hasil Analisis Regresi Linier Berganda Coefficients $^{\mathrm{a}}$

\begin{tabular}{|l|l|l|l|l|l|}
\hline \multirow{2}{*}{ Model } & Unstandardized & \multicolumn{2}{|l|}{$\begin{array}{l}\text { Standardized } \\
\text { Coeff icients }\end{array}$} & \multicolumn{2}{|l|}{} \\
\cline { 2 - 6 } & $\mathrm{B}$ & Std. Error & Beta & $\mathrm{t}$ & sig \\
\hline 1 & & & & & \\
(Constant) & -1.335 & 1.035 & & -1.290 & .238 \\
RWC & .596. & .038 & .976 & 15.718 & .000 \\
C R. & -.001 & 001 & -.043 & -.692 & .511 \\
& & & & & \\
\hline
\end{tabular}

a. Dependent Variable: ROI

Dari tabel diatas dibentuk persamaan regresi linier sebagai berikut :

$\mathrm{Y}=-1,335+0,596 \mathrm{X} 1-0,001 \mathrm{X} 2$

Koefisien yang terdapat pada persamaan diatas dapat dijelaskan sebagai berikut : (1) Konstanta sebesar -1,335 persen menunjukkan rata-rata profitabilitas pada PT Mayora Indah Tbk jika efisiensi modal kerja dan likuiditas sama dengan nol; (2) Efisiensi modal kerja memiliki koefisien bertanda positif sebesar 0,595 persen, artinya setiap peningkatan efisiensi modal kerja sebesar 1 persen diprediksi akan meningkatkan profitabilitas sebesar 0,596 persen, dengan asumsi likuiditas tidak berubah; (3) Likuiditas memiliki koefisien bertanda negatif sebesar 0,001 persen, artinya setiap penurunan likuiditas sebesar 1 persen diprediksi akan meningkatkan profitabilitas sebesar 0,001 persen dengan asumsi efisiensi modal kerja tidak berubah.

Korelasi ganda merupakan angka yang menunjukan kekuatan hubungan antar kedua variabel bebas secara bersama-sama dengan variabel profitabilitas. Hubungan korelasi secara simultan dapat dilihat pada tabel berikut :

Tabel 4.9 Analisis Koefisien Korelasi Berganda dan Koefisien Determinasi Model Summaryb

\begin{tabular}{|c|c|c|c|c|c|}
\hline Model & $\mathrm{R}$ & $\mathrm{R}$ Square & $\begin{array}{c}\text { Adjusted R } \\
\text { Square }\end{array}$ & $\begin{array}{c}\text { Std error of } \\
\text { estimate }\end{array}$ & $\begin{array}{c}\text { Durbin } \\
\text { watson }\end{array}$ \\
\hline 1 & $.987 \mathrm{a}$. & .975 & .967 & .63055 & 1.925 \\
\hline
\end{tabular}

a. Predictors: (Constant), CR, RWC

b. Dependent Variable: ROI

Berdasarkan data pada tabel 4.12 diatas dapat dilihat bahwa nilai koefisien korelasi ganda adalah sebesar 0,987 yang berada antara 0,80 - 1,00, artinya efisiensi modal kerja dan likuiditas secara simultan memiliki hubungan yang sangat kuat dengan profitabilitas.

Koefisien determinasi digunakan untuk melihat seberapa besar variabel efisiensi modal kerja dan likuiditas secara bersama-sama berpengaruh terhadap profitabilitas. Untuk nilai koefisien determinasi dapat dilihat pada tabel 4.12 tepatnya dilihat dari nilai $\mathrm{R}$ Square 


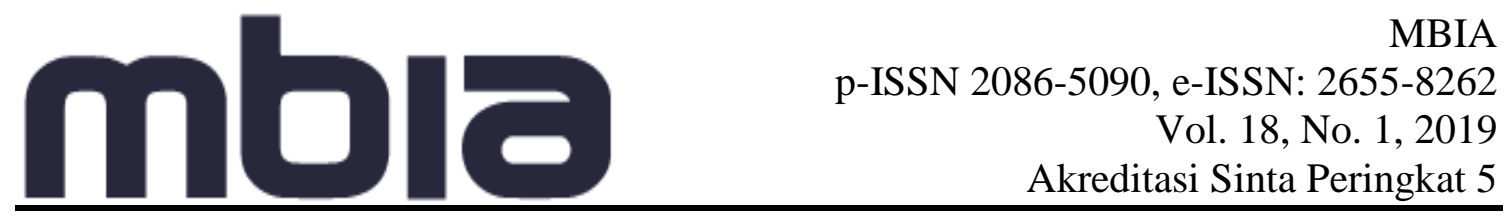

yaitu sebesar 0,975 atau 97,5\%, artinya pengaruh efisiensi modal kerja dan likuiditas secara simultan terhadap profitabilitas sebesar $97,5 \%$, sedangkan sisanya yaitu $2,5 \%$ merupakan pengaruh faktor-faktor lain yang tidak diteliti pada penelitian ini seperti faktor penjualan (Ima Kristiana, 2003).

\section{Simpulan}

Dari hasil perhitungan dan analisis yang dilakukan, maka diperoleh bentuk hubungan linier dari efisiensi modal kerja dan likuiditas digunakan analisis regresi linier berganda : $\mathrm{Y}=-1,335+0,596 \mathrm{X} 1-0,001 \mathrm{X} 2$, koefisien yang terdapat pada persamaan dapat dijelaskan sebagai berikut : (a) Konstanta sebesar -1,335 persen menunjukkan rata-rata profitabilitas pada PT Mayora Indah, Tbk jika efisiensi modal kerja dan likuiditas sama dengan nol; (b) Efisiensi modal kerja memiliki koefisien bertanda positif sebesar 0,595 persen, artinya setiap peningkatan efisiensi modal kerja sebesar 1 persen diprediksi akan meningkatkan profitabilitas sebesar 0,596 persen, dengan asumsi likuiditas tidak berubah; (c) Likuiditas memiliki koefisien bertanda negatif sebesar 0,001 persen, artinya setiap penurunan likuiditas sebesar 1 persen diprediksi akan meningkatkan profitabilitas sebesar 0,001 persen dengan asumsi efisiensi modal kerja tidak berubah; (d) bahwa nilai koefisien korelasi ganda adalah sebesar 0,987 yang berada antara 0,80 - 1,00, artinya efisiensi modal kerja dan likuiditas secara simultan memiliki hubungan yang sangat kuat dengan profitabilitas; (e) Untuk nilai koefisien determinasi dapat dilihat pada tabel 4.12 tepatnya dilihat dari nilai R Square yaitu sebesar 0,975 atau 97,5\%, artinya pengaruh efisiensi modal kerja dan likuiditas secara simultan terhadap profitabilitas sebesar 97,5\%, sedangkan sisanya yaitu 2,5\% merupakan pengaruh faktor-faktor lain yang tidak diteliti pada penelitian ini seperti faktor penjualan

\section{Daftar Pustaka}

Astuti, I. (2013). Pengaruh manajemen modal kerja terhadap profitabilitas Perusahaan Automotive and Allied Product yang Go Publik di BEJ.

Brigham, F, E., \& Houston, F, J. (2011). Manajemen Keuangan. Jakarta: Erlangga.

Dani. (2013). Pengaruh likuiditas, leverage dan efisiensi modal kerja terhadap profitabilitas (Studi kasus pada PT Modern Toolsindo Bekasi).

Singangerda, F.IS. (2014), analisis pengaruh modal kerja terhadap profitabilitas dan rentabilitas pada Koperasi Dharma Wanita Mandalika Mataram Nusa Tengggra Barat. Jurnal Manajemen Keuengan, 2(1).

Ghozali, I. (2011). Aplikasi Analisis Multivariante dengan Program SPSS Edisi 2. Semarang: UNDIP.

Hanafi, M., \& dan Halim, A. (2005). Analisis Laporan Keuangan. Yogyakarta: AMPYKPN.

Husnan, S. (2015). Manajemen Keuangan teori dan Penerapan (Keputusan Jangka Panjang). Yogyakarta: BPFE

Indonesian Capital Market Directory 2001-2005. (2005). Jakarta: Bursa efek Jakarta.

Nurgraeni, S. (2015). Analisis Pengaruh Efisiensi Modal Kerja, Likuiditas, dan Solvabilitas Terhadap Profitabilitas Pada Perusahaan Property And Real Estate Yang Go Publik di Bursa Efek Jakarta.

Riyanto, B. (2015). Dasar-dasar Pembelanjaan Perusahaan. Yogyakarta: BPFE.

Rangkuti, F. (2004). Analisis SWOT Teknik Membedah Kasus Bisnis. Jakarta: PT Gramedia Pustaka Utama. 
Santoso, S. (2004). Buku Latihan SPSS Statistik Parametrik. Jakarta: PT Elex Media Komputindo

Sawir, A. (2001). Analisis Kinerja Keuangan dan Perencanaan Keuangan Perusahaan. Jakarta: PT Gramedia Pustaka Utama

Sartono, A. (1998). Manajemen Keuangan Teori dan Aplikasi. Yogyakarta: BPFE.

Soehartono, I. (1999). Metode Penelitian Sosial. Bandung: PT Remaja Rosdakarya

Tunggal, W. (2015). Dasar-dasar Analisis Laporan Keuangan. Yogyakarta: Rhineka Cipta.

Usman, H., \& Akbar, S.P. (2003). Pengantar Statistika. Jakarta: PT Bumi Aksara.

Weston, J.F., \& Copeland, T.E. (1997), Manajemen Keuangan, Edisi Kedelapan, Jakarta: Erlangga.

\section{Copyright Disclaimer}

Copyright for this article is retained by the author(s), with first publication rights granted to the journal. 